\title{
Macro and Microscopic Characters of the Aerial Vegetative Organs of Carqueja: Baccharis usterii Heering
}

\author{
Jane Manfron Budel and Márcia do Rocio Duarte* \\ Laboratório de Farmacognosia; Departamento de Farmácia; Universidade Federal do Paraná; Av. Pref. Lothário \\ Meissner, 632; Jardim Botânico; 80210-170; Curitiba, Paraná, Brazil
}

\begin{abstract}
This work aimed to study the macro and microscopic characters of the aerial vegetative organs of Baccharis usterii for quality control purposes. The plant was prepared for light and scanning electron microscopic analyses. The stem consisted of three-winged cladodes with small leaves. In the caulinar axis, these was a uniseriate epidermis, chlorenchyma alternating with angular collenchyma, perivascular fibre caps adjoining the phloem which was outside the xylem, and parenchymatic pith. The wings and the leaves were alike, presenting a uniseriate epidermis, palisade parenchyma next to the both sides of the epidermis and spongy parenchyma traversed by minor collateral vascular bundles in the central region. In the leaf midrib, a single collateral vascular bundle was embedded in the ground parenchyma. Secretory ducts and glandular trichomes occured in the stem and leaf.
\end{abstract}

Key words: Baccharis usterii, Carqueja, Medicinal plant, Morpho-anatomy, Secretory ducts

\section{INTRODUCTION}

The genus Baccharis L. (Asteraceae) comprises about 500 species, distributed from the United States to Argentina, mainly in South America. Several members of the taxon are relevant as medicinal plants (Zardini, 1984; Verdi et al., 2005), ornamentals (Carneiro \& Fernandes, 1996) and source of essential oil for industry (Boldt, 1989; Agostini et al., 2005). Some species which exhibit caulinar expansions forming cladodes are commonly known as carqueja and are considered diuretic and stomachic in Brazilian and Argentina folk medicine (Corrêa, 1984; Alonso, 1998; Castro \& Ferreira, 2001). Pharmacological essays have demonstrated anti-ulcer (Baggio et al., 2003), antispasmodic (Torres et al., 2000; Weimann et al., 2002), anti-inflammatory (Muschietti et al., 1998; Cifuente et al., 2001), antimicrobial (Cobos et al., 2001; Feresin et al., 2001; 2003) and antioxidant activities (Mongelli et al., 1997; Heras et al., 1998).

Baccharis trimera (Less.) DC. is claimed to be the most popular and investigated species, and it has been recently included in the Farmacopéia Brasileira IV (2003). It is a perennial shrub which may attain $1 \mathrm{~m}$ heigh and presents three-winged cladodes with no leaves or reduced ones, and is chemically evaluated in terms of flavonoid and essential oil contents. Similar in appearance, Baccharis usterii Heering (Fig. 1a) is a small shrub having three-winged cladodes, although it shows sparse leaves (Barroso, 1976; Barroso \& Bueno, 2002; Farmacopéia Brasileira, 2003). It

*Author for correspondence: janemanfronb@uol.com.br 
plays a relevant role in folk medicine, despite the lack of available information on this species.

Since carquejas are one of the most commercialized medicinal plants in Brazil (Correia-Júnior et al., 1991) and their morphoanatomical identification is required for quality control in phytotherapy industry, this work aimed to study the macro and microscopic characters of the aerial vegetative organs of $B$. usterii.

\section{MATERIALS AND METHODS}

The plant material was collected at the Fazenda São Maximiano, located in the region of Serra do Sudoeste, in the city of Guaíba, state of Rio Grande do Sul, Brazil (coordinates $30^{\circ} 10^{\prime} \mathrm{S}$ and $51^{\circ} 20^{\prime} \mathrm{W}$, and $27 \mathrm{~m}$ high), in December 2003. The voucher was identified and registered as ICN53622 in the Herbarium at the Instituto de Ciências Naturais, Universidade Federal do Rio Grande do Sul.

Cladode fragments obtained $5 \mathrm{~cm}$ from the apex and adult leaves were collected from at least five specimens and fixed in FAA 70 (Johansen, 1940), which was replaced by $70 \%$ ethanol (Berlyn \& Miksche, 1976). The material was either sectioned by hand or dehydrated, embedded in glycolmethacrylate (Leica historesin ${ }^{\circledR}$ ) and sectioned using the microtome Leica RM-2145. Transverse and longitudinal sections were stained with toluidine blue (O'Brien et al., 1964) or astra blue and basic fuchsine combination (Roeser, 1972).

The following standard solutions were employed for microchemical tests: hydrochloric phloroglucin to reveal lignin (Sass, 1951), Sudan III for lipophilic compounds (Foster, 1949), ferric chloride for phenolic substances (Johansen, 1940), sulphuric acid for calcium oxalate crystals (Oliveira et al., 1991) and iodine-iodide for starch (Berlyn \& Miksche, 1976). Photomicrographs were taken with the light microscope Olympus BX-40 equipped with the control unit PM-20.

For scanning electron analysis (SEM) (Souza, 1998), the fixed material was dehydrated in a graded ethanolic series and by $\mathrm{CO}_{2}$ critical point apparatus Balzers CPD-030 and coated with gold by Balzers Sputtering SCD-030. Electron micrographs were taken with the scanning microscope Jeol JSM-6360LV.

\section{RESULTS}

The stem (Fig. 1a) achieved height of $1 \mathrm{~m}$ and consisted of cladodes with three expansions or wings. The axis was rigid and the wings were discontinuous and regularly distributed around it. In the cladode cross-section, the axis tended to be circular shaped and exhibited ribs between the wings (Figs. 1b, 2a).

In the wings, the epidermal cells were polygonal and had thick anticlinal walls with evident primary pits on surface view. The epidermis was uniseriate (Figs. 1c, 1d) and coated with a thin and slightly striate cuticle (Fig. 1e). Anomocytic stomata were located at the same level or nearly above the surrounding cells, and glandular trichomes were inserted in small epidermal depressions. They were non-capitate, multicellular and uniseriate (Figs. 1d, 1f) or capitate and biseriate (Fig. 1e). The chlorenchyma consisted of a palisade parenchyma, composed of approximately three strata of short cells below both sides of the epidermis, and a spongy parenchyma in the central region. Minor collateral vascular bundles encircled by a parenchymatic sheath traversed the spongy parenchyma (Fig. 1c).

Each bundle directed the xylem to the upper and lower side alternately. One or more secretory ducts, presenting uniseriate epithelium, dense cytoplasm, evident nucleus and lipophilic content, were found next to the parenchymatic sheath, in the phloem direction.

At the wing borders, there were several layers of angular collenchyma below the epidermis, a collateral vascular bundle with a perivascular fibre cap adjoining the phloem and secretory ducts (Fig. 1c). In the caulinar axis, the epidermis showed the same characteristics of the wings and, below it was the chlorenchyma alternate with angular collenchyma, which had about eight rows in the ribs (Fig. 2a). Secretory ducts, similar to the ones in the wings, was encountered next to the parenchymatic sheath that limited internally the cortex (Fig. 2b) and whose walls were impregnated with lipophilic compounds. The vascular cylinder presented cambia forming phloem outward and xylem inward (Fig. 2d), and perivascular fibre caps adjoined the phloem. The xylem was completely lignified. 

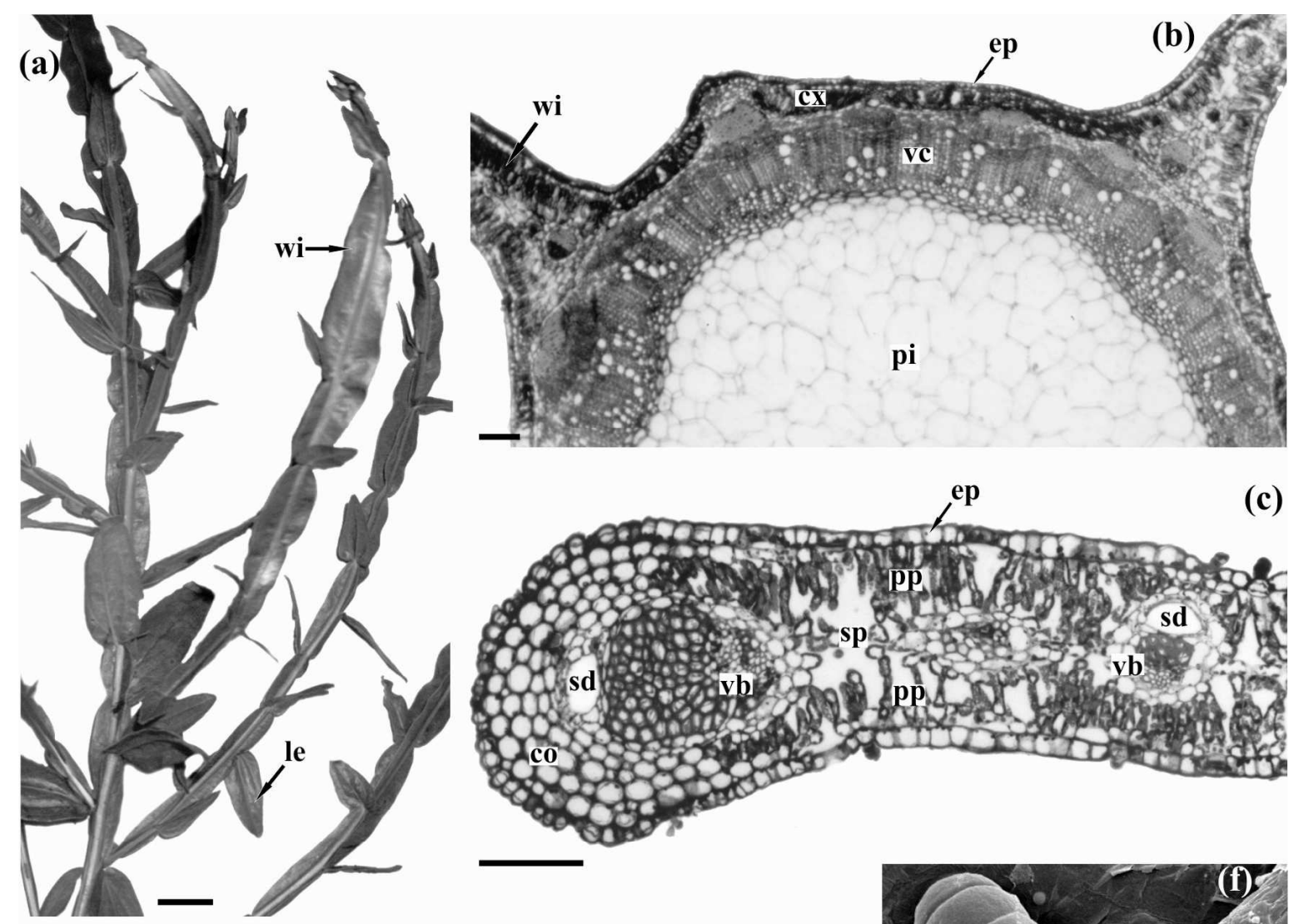

(d)
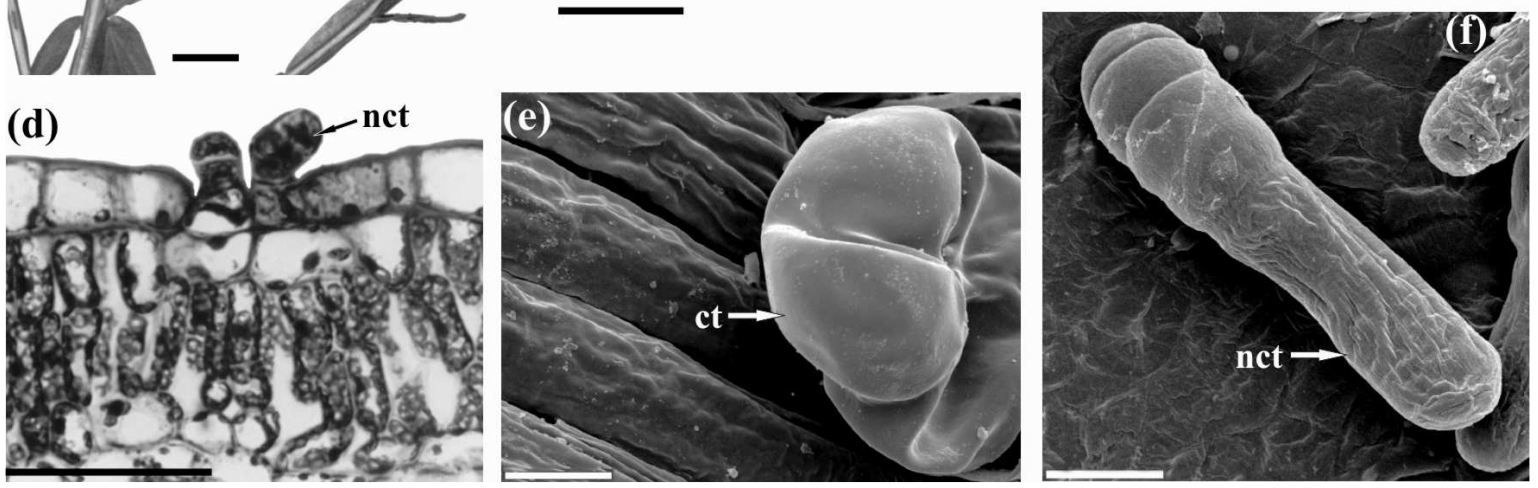

Figure 1 - Baccharis usterii Heering. (a) Aspect of aerial vegetative organs, showing cladodes and leaves; (b) cladode cross-section, exhibiting a rib between the wings; (c) wing crosssection near the border; (d) non-capitate glandular trichomes; (e) capitate glandular trichome and striate cuticle (SEM); (f) non-capitate glandular trichome (SEM). co: collenchyma; ct: capitate glandular trichome; cx: cortex; ep: epidermis; le: leaf; nct: non-capitate glandular trichome; pi: pith; pp: palisade parenchyma; sd: secretory duct; sp: spongy parenchyma; vb: vascular bundle; vc: vascular cylinder; wi: wing. Bar =

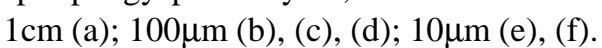



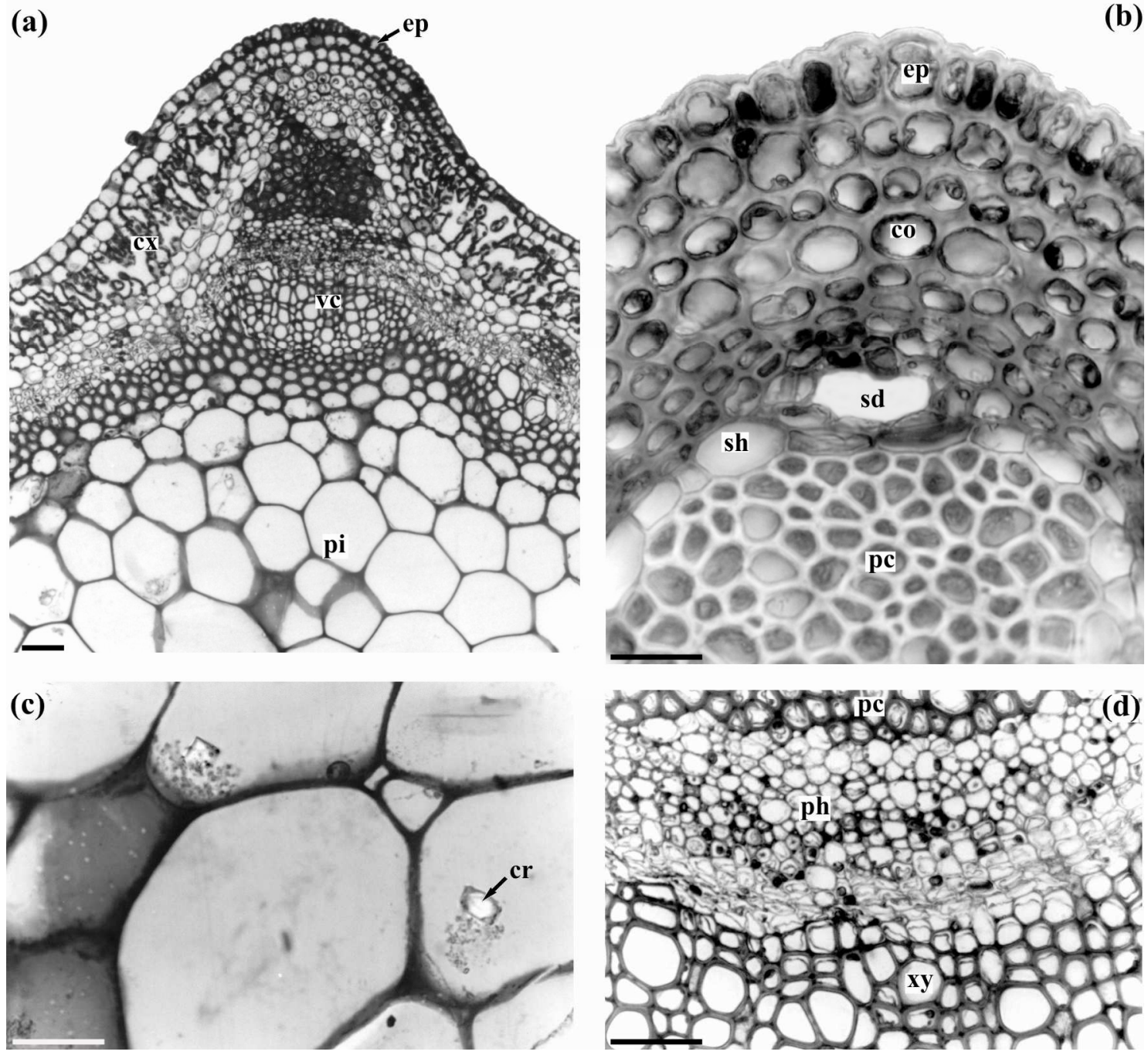

Figure 2 - Stem axis cross-section of Baccharis usterii Heering. (a) Organization of the rib region; (b) detail of the previous figure, showing angular collenchyma, secretory duct, parenchymatic sheath and perivascular fibre cap; (c) prisms of calcium oxalate in the pith; (d) phloem and xylem arrangement in the vascular cylinder. co: collenchyma; cr: crystal; cx: cortex; ep: epidermis; pc: perivascular fibre cap; ph: phloem; pi: pith; sd: secretory duct; sh: parenchymatic sheath; vc: vascular cylinder; xy: xylem. Bar = $50 \mu \mathrm{m}$.

The pith occupied most part of the stem volume and was formed by relatively large parenchymatic cells with thin walls. Small prisms of calcium oxalate occured in the perimedular region (Fig. 2c).

The leaf (Fig. 1a) had ovate shape, acute apex, cordate base and approximately $3 \mathrm{~cm}$ of length and $1.5 \mathrm{~cm}$ of width. It was sessile and exhibited three larger veins, being the midvein prominent on the abaxial side. The blade had a uniseriate epidermis (Fig. 3c), composed of polygonal-shaped cells with moderately thick anticlinal walls (Figs. 3a, $3 b)$, exhibiting primary pits on surface view. The dermal system was coated with a thin and slightly striate cuticle. Anomocytic stomata occurred on both sides (Figs. 3a, 3b) and they were even or slightly above the other epidermal cells (Fig. 3d). Glandular trichomes, similar to the cladode, were observed on both surfaces and placed in small depressions. The mesophyll was isobilateral, comprising a palisade parenchyma with three or four layers of relatively short cells below the 
epidermis, and a spongy parenchyma with about two strata of cells forming small intercellular spaces in the central region (Fig. 3c). Collateral vascular bundles traversed the spongy parenchyma and were encircled by a parenchymatic sheath that was accompanied by secretory ducts in the phloem direction (Fig. 3d).

The midrib (Fig. 3e), in cross-section, was slightly convex on the adaxial side and convex on the opposite surface. The uniseriate epidermis was coated with a slightly striate cuticle and the chlorenchyma was interrupted and replaced by various layers of angular collenchyma on both sides. A single vascular bundle, collateral and ovate shaped, was embedded in the ground parenchyma and had caps of perivascular fibres adjoining the xylem and phloem, at different stages of lignification. It was enclosed in a parenchymatic sheath and associated with secretory ducts nearby the phloem (Fig. 3f). These secretory structures showed an epithelium formed by four to ten cells arranged in one stratum.
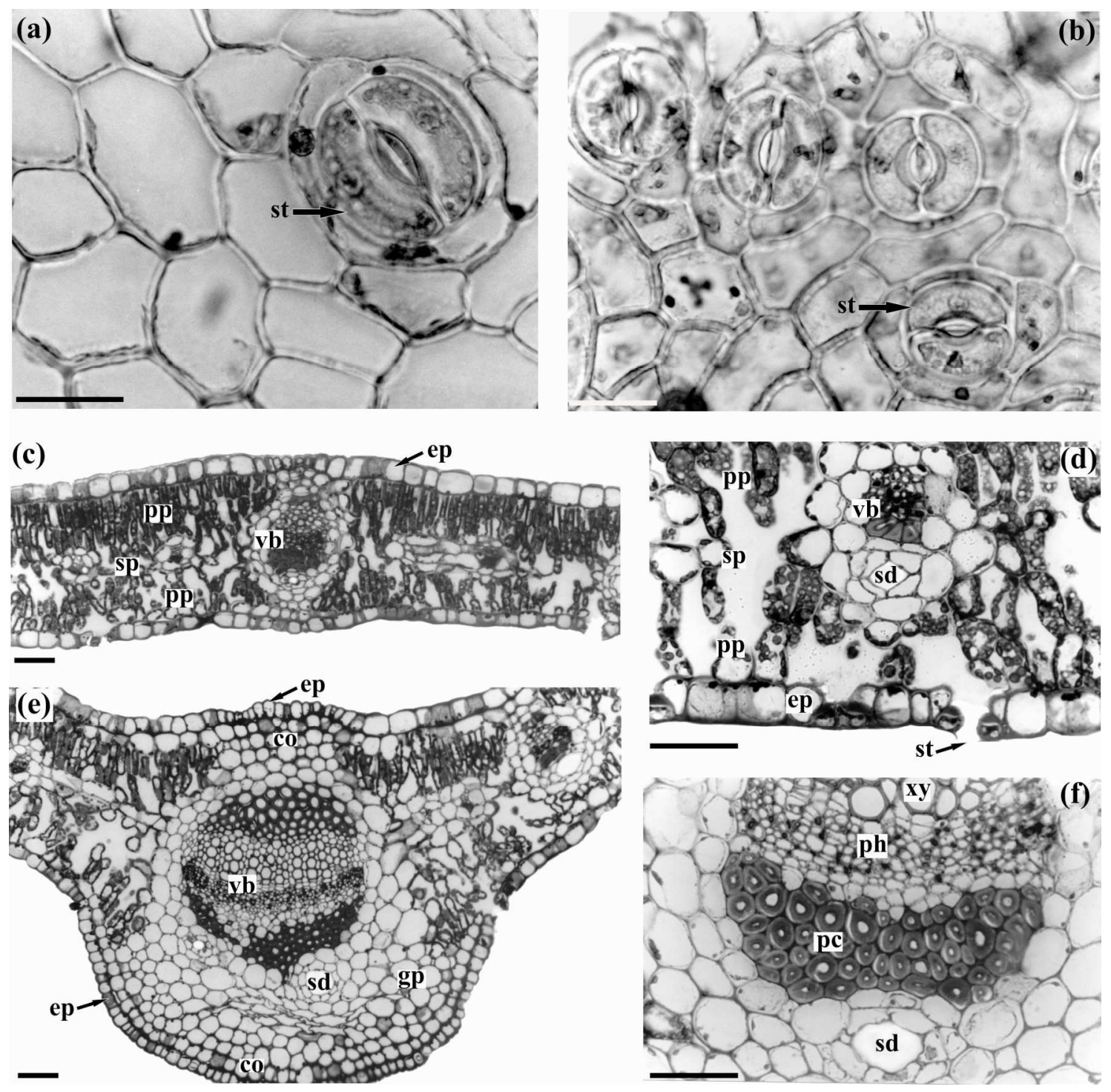

Figure 3 - Leaf cross-section of Baccharis usterii Heering. (a), (b) Adaxial and abaxial side of the epidermis, in surface view, respectively; (c), (d) blade organization, revealing isobilateral mesophyll; (e), (f) midrib traversed by a collateral vascular bundle associated with secretory ducts. co: collenchyma; ep: epidermis; gp: ground parenchyma; pc: perivascular fibre cap; ph: phloem; pp: palisade parenchyma; sd: secretory duct; sp: spongy parenchyma; st: stomatum; vb: vascular bundle; xy: xylem. Bar $=50 \mu \mathrm{m}$. 


\section{DISCUSSION}

Owing to the characteristic features of the cladodes, they are considered important for the diagnosis of vegetal drugs, such as carquejas (Oliveira et al., 1991). The occurrence of these caulinar expansions has been mentioned in Baccharis, particularly in the Trimera group which comprises shrubs with winged stems, whose expansions are continuous or discontinuous forming different sized segments (Barroso, 1991; Barroso \& Bueno, 2002). Considering this group, B. usterii differs from B. articulata (Lam.) Pers. as the latter displays two-wings (Ariza-Espinar, 1973; Cortadi et al., 1999; Ortins \& Akisue, 2000), and from B. stenocephala Baker which presents both two and three expansions (Barroso \& Bueno, 2002). Regarding the three-winged species B. cylindrica (Less.) DC. (Budel et al., 2004a), B. gaudichaudiana DC. (Budel et al., 2003a), B. myriocephala DC. (Sá \& Neves, 1996) and $B$. trimera (Jorge et al., 1991; Cortadi et al., 1999; Farmacopéia Brasileira, 2003; Budel et al., 2003b), B. usterii shows leaves that are lacking or inconspicuous in these species.

With reference to microscopic characters, the caulinar axis showing remaining epidermis, strands of chlorenchyma alternating with collenchyma, either endodermis or starch sheath limiting internally the cortex and vascular cambia forming phloem outward and xylem inward are common features of Asteraceae (Metcalfe \& Chalk, 1950) and described in Baccharis (ArizaEspinar, 1973; Sá \& Neves, 1996; Cortadi et al., 1999; Ortins \& Akisue, 2000). Additionally, included phloem may occur in the family (Metcalfe \& Chalk, 1950), as in B. cylindrica (Budel et al., 2004a). These aspects were observed in this investigation, except for the phloem.

The occurrence of calcium oxalate crystals is frequent in plants, although their size and number are responsive to changes in the concentration of calcium in the environment (Nakata, 2003). These crystals have been reported in B. articulata (ArizaEspinar, 1973; Cortadi et al., 1999; Ortins \& Akisue, 2000; Budel et al., 2003b), B. cylindrica (Budel et al., 2003b; Budel et al., 2004a), B. gaudichaudiana (Budel et al., 2003a; Budel et al., 2003b), B. myriocephala (Sá \& Neves, 1996) and B. trimera (Cortadi et al., 1999; Farmacopéia Brasileira, 2003; Budel et al., 2003b), as well as in B. usterii.
The cladode plays a photosynthetic role and the wings have microscopic characteristics similar to the leaf. For Metcalfe and Chalk (1988), the cuticle ornamentation may be relevant for diagnostic purposes. As found in the species studied, striate cuticle has been cited for the genus (Ariza-Espinar, 1973) and for B. cylindrica (Budel et al., 2003b; Budel et al., 2004a), B. gaudichaudiana (Budel et al., 2003a; Budel et al., 2003b), B. retusa (Silva \& Grotta, 1971) and B. trimera (Cortadi et al., 1999; Budel et al., 2003b). In Asteraceae, the stomata may occur on both sides of the blade and they are anomocytic or anisocytic, being the former predominant (Metcalfe \& Chalk, 1950). These types have been cited for Baccharis (Ariza-Espinar, 1973) and in B. articulata (Ariza-Espinar, 1973; Cortadi et al., 1999; Ortins \& Akisue, 2000; Budel et al., 2003b), B. cylindrica (Budel et al., 2003b; Budel et al., 2004a), B. gaudichaudiana (Budel et al., 2003a; Budel et al., 2003b), B. retusa (Silva \& Grotta, 1971) and B. trimera (Budel et al., 2003b; Alquini \& Takemori, 2000). Concerning B. myriocephala, beside these two types, tetracytic stomata have also been described (Sá \& Neves, 1996). Accordingly, B. usterii shows anomocytic stomata. Seen as epidermal appendages of microscopic diagnostic value, glandular and non-glandular trichomes are referred to Baccharis for Metcalfe \& Chalk (1988) and Ariza-Espinar (1973). In this work, multicellular capitate and non-capitate glandular trichomes were encountered in the leaf and cladode. Similar trichomes have been reported in B. articulata (Ariza-Espinar, 1973; Cortadi et al., 1999; Ortins \& Akisue, 2000; Budel et al., 2003b), B. mesoneura DC. (Barroso, 1976), B. myriocephala (Sá \& Neves, 1996) and B. trimera (Cortadi et al., 1999; Farmacopéia Brasileira, 2003; Budel et al., 2003b). As regards as nonglandular trichomes, they are often reported in different species of Baccharis, e.g., B. anomala DC. (Barroso, 1976), B. artemisioides Hook. et Arn., B. lilloi Heering, B. pulchella Sch. Bip., B. rupestris Heering, B. salicifolia (Ruiz et Pav.) Pers. (Ariza-Espinar, 1973) and B. trimera (Farmacopéia Brasileira, 2003). These appendages have in common being multicellular (two to eight cells), uniseriate and with a relatively long to whip-like apical cell (Ariza-Espinar, 1973). Nevertheless, non-glandular trichomes are not observed in B. usterii.

In the family, the chlorenchyma organization 
varies (Metcalfe \& Chalk, 1950) and the isobilateral mesophyll described in the blade of $B$. usterii by Barroso (1976) was confirmed in this investigation and also mentioned in $B$. dracunculifolia (Oliveira \& Bastos, 1998; Budel et al., 2004b) and B. retusa (Silva \& Grotta, 1971). This organization has correspondence to the chlorenchyma arrangement in the wings of $B$. articulata (Ariza-Espinar, 1973; Cortadi et al., 1999; Ortins \& Akisue, 2000; Budel et al., 2003b), B. cylindrica (Budel et al., 2004a); Budel et al., 2003b), B. gaudichaudiana (Budel et al., 2003a; Budel et al., 2003b) and B. myriocephala (Sá \& Neves, 1996). However, contradictory information on B. trimera reveals dorsiventral mesophyll (Farmacopéia Brasileira, 2003) or homogeneous mesophyll either with palisade parenchyma (Cortadi et al., 1999) or spongy parenchyma (Jorge et al., 1991; Chicourel et al., 1997). As observed in this study and well registered in various species of Baccharis, the vascular bundles were collateral and there was an association with them and secretory ducts (Silva \& Grotta, 1971; Ariza-Espinar, 1973; Sá \& Neves, 1996; Oliveira \& Bastos, 1998; Cortadi et al., 1999; Ortins \& Akisue, 2000; Budel et al., 2003a; Budel et al., 2004a). According to Pagni and Masini (1999), in many members of Asteraceae, the ducts were usually related to the endodermis, were next to the phloem, the secretory structures were associated with this conducting system.

\section{CONCLUSIONS}

As expected, the macro and microscopic aspects of the aerial vegetative organs of B. usterii agreed with the Baccharis genus. These characters should be evaluated as a whole to characterize the species, although the following structures might be emphasized as distinguishing features among the Trimera group: three-winged cladode accompanied by leaves, striate cuticle, anomocytic stomata, multicellular capitate and non-capitate glandular trichomes, isobilateral mesophyll and secretory ducts in the phloem direction.

\section{ACKNOWLEDGMENTS}

The authors gratefully acknowledge the taxonomist N.I. Matzenbacher for the species identification and the Centro de Microscopia Eletrônica at the Universidade Federal do Paraná for the electron micrographs.

\section{RESUMO}

Caracteres macro e microscópicos dos órgãos vegetativos aéreos de carqueja: Baccharis usterii Heering. Este trabalho objetivou estudar os caracteres macro e microscópicos dos órgãos vegetativos aéreos de Baccharis usterii, com aplicação no controle de qualidade. O material botânico foi preparado de acordo com técnicas para microscopia óptica e de varredura. O caule consistiu de cladódios trialados, nos quais se inserem pequenas folhas. $\mathrm{O}$ eixo caulinar apresentou epiderme unisseriada, clorênquima em alternância com colênquima angular, calotas de fibras perivasculares apostas ao floema, o qual se forma externamente ao xilema, e medula parenquimática. As alas e as folhas mostraram-se semelhantes, apresentando epiderme unisseriada, parênquima paliçádico junto a ambas as faces epidérmicas e parênquima esponjoso na região central, atravessado por feixes vasculares de pequeno porte. Na nervura central da folha, um feixe vascular colateral encontrou-se mergulhado no parênquima fundamental. Dutos secretores e tricomas glandulares ocorreram no caule e na folha

\section{REFERENCES}

Agostini, F.; Santos, A. C. A.; Rossato, M.; Pansera, M. R.; Zattera, F.; Wasum, R. and Serafini, L. A. (2005), Estudo do óleo essencial de algumas espécies do gênero Baccharis (Asteraceae) do sul do Brasil. Rev. Bras. Farmacognosia, 15, 215-220.

Alonso, J. R. (1998), Tratado de fitomedicina - bases clínicas y farmacológicas. Isis, Buenos Aires.

Alquini, Y. and Takemori, N. K. (2000), Organização estrutural de espécies vegetais de interesse farmacológico. Herbarium, Curitiba.

Ariza-Espinar, L. (1973), Las especies de Baccharis (Compositae) de Argentina Central. Bol. Acad. Nac. Cienc. Córdoba, 50, 176-305.

Baggio, C. H.; Freitas, C. S.; Rieck, L. and Marques, M. C. A. (2003), Gastroprotective effects of a crude extract of Baccharis illinita DC. in rats. Pharmacol. Res., 47, 93-98.

Barroso, G. M. (1976), Compositae - Subtribo Baccharidinae Hoffmann - Estudo das espécies ocorrentes no Brasil. Rodriguésia, 28, 1-273. 
Barroso, G. M. (1991), Sistemática de angiospermas do Brasil. Universitária, Viçosa. vol. 3.

Barroso, G. M. and Bueno, O. L. (2002), Compostas: subtribo Baccharidinae. Herbário Barbosa Rodrigues, Itajaí.

Berlyn, G. P. and Miksche, J. P. (1976), Botanical microtechnique and cytochemistry. Iowa State University, Ames.

Boldt, P. E. (1989), Baccharis (Asteraceae) - a review of its taxonomy, phytochemistry, ecology, economic status, natural enemies and the potential for its biological control in the United States. College Station, Texas.

Budel, J. M.; Duarte, M. R. and Santos, C. A. M. (2003a), Caracteres morfo-anatômicos de Baccharis gaudichaudiana DC., Asteraceae. Acta Farm. Bonaerense, 22, 313-320.

Budel, J. M.; Duarte, M. R.; Santos, C. A. M. and Cunha, L. M. (2003b), Macro and macroscopical identification of four species of Baccharis from Trimera group. Rev. Bras. Farmacognosia, 13, 42-43.

Budel, J. M.; Duarte, M. R. and Santos, C. A. M. (2004a), Stem morpho-anatomy of Baccharis cylindrica (Less.) DC., Asteraceae. Braz. J. Pharm. Sci., 40, 93-99.

Budel, J. M.; Duarte, M. R. and Santos, C. A. M. (2004b), Morfoanatomia foliar e caulinar de Baccharis dracunculifolia DC., Asteraceae Acta Farm. Bonaerense, 23, 477-483.

Carneiro, M. A. A. and Fernandes, G. W. (1996), Herbivoria. Ciênc. Hoje, 20, 35-39.

Castro, H. G. and Ferreira, F.A. (2001), Contribuição ao estudo das plantas medicinais: Carqueja. UFV: Minas Gerais.

Chicourel, E. L.; Pimenta, D. S.; Jorge, L. I. F. and Ferro V. O. (1997), Contribuição ao conhecimento analítico de três compostas medicinais. Rev. Bras. Farmacognosia, 7, 59-66.

Cifuente, D. A.; Simirgiotis, M. J.; Favier, S.; Rotelli, A. E. and Pelzer, L. E. (2001), Anti-inflammatory activity from aerial parts of Baccharis medullosa, Baccharis rufescens and Laennecia sophiifolia in mice. Phytother. Res., 15, 529-531.

Cobos, M. I.; Rodríguez, J. L.; Oliva, M. L. M.; Demo, M.; Faillaci, S. M. and Zygadlo, J. A. (2001), Composition and antimicrobial activity of the essential oil of Baccharis notosergila. Planta Med., 67, 84-86.

Corrêa, M. P. (1984), Dicionário das plantas úteis do Brasil e das exóticas cultivadas. Rio de Janeiro: IBDF.

Correa-Júnior, C.; Ming, L. C. and Scheffer, M. C. (1991), Cultivo de plantas medicinais, condimentares e aromáticas. Curitiba: Emater-PR.

Cortadi, A.; Di Sapio, O.; McCargo, J.; Scandizzi, A.; Gattuso, S. and Gattuso, M. (1999), Anatomical studies of Baccharis articulata, Baccharis crispa e
Baccharis trimera, "Carquejas" used in folk medicine. Pharm. Biol., 37, 357-365.

Farmacopéia Brasileira. (2003), 4 ed. São Paulo: Atheneu.

Feresin, G. E.; Tapia, A.; López, S. N. and Zacchino, A. S. (2001), Antimicrobial activity of plants used in tradicional medicine of San Juan province, Argentine. J. Ethnopharmacol., 78, 103-107.

Feresin, G. E.; Tapia, A.; Jiménez, A.; Ravelo, A. G.; Zacchino, S.; Sortino, M. and Schmeda-Hirschmann, G. (2003), Constituents of the Argentinian medicinal plant Baccharis grisebachii and their antimicrobial activity. J. Ethnopharmacol., 89, 73-80.

Foster, A. S. (1949), Practical plant anatomy. 2nd ed. Princeton: D. Van Nostrand.

Heras, B.; Slowing, K.; Benedí, J.; Carretero, E.; Ortega, T.; Gómez-Serranillos, P.; Liso, P.A.; Villar, A. and Ciribora, X. (1998), Anti-inflammatory and antioxidant activity of plants used in traditional medicine in Ecuador. J. Ethnopharmacol., 61, 161166.

Johansen, D. A. (1940), Plant microtechnique. New York: McGraw-Hill.

Jorge, L. I. F.; Pereira, U. and Silva, A. M. (1991), Identificação histológica das principais compostas brasileiras de emprego medicinal. Rev. Inst. Adolfo Lutz, 51, 47-51.

Metcalfe, C. R. and Chalk, L. (1950), Anatomy of the dicotyledons: leaves, stem, and woods in relation to taxonomy with notes on economic uses. Oxford: Clarendon.

Metcalfe, C. R. and Chalk, L. (1988), Anatomy of the dicotyledons. Oxford: Clarendon. vol. 1.

Mongelli, E.; Demarchelier, C.; Talou, J. R.; Coussio, J. and Ciccia, G. (1997), In vitro antioxidant and cytotoxicity activity of extracts of Baccharis coridifolia DC. J. Ethnopharmacol., 58, 157-163.

Muschietti, L.; Martino, V.; Ferraro, G.; Coussio, J.; Segura, L.; Cartaná, C.; Canigueral, S. and Adzet, T. (1998), The anti-inflammatory effect of some species from South America. Phytother. Res. 10, 84-86.

Nakata, P. A. (2003), Advances in our understanding of calcium oxalate crystal formation and function in plants. Plant Sci., 164, 901-909.

O'Brien, T. P.; Feder, N. and McCully, M. E. (1964), . Polychromatic staining of plant cell walls by toluidine blue O. Protoplasma, 59, 368-373.

Oliveira, F.; Akisue, G. and Akisue, M. F. (1991), Farmacognosia. Rio de Janeiro: Atheneu.

Oliveira, V. C. and Bastos, E. M. (1998), Aspectos morfo-anatômicos da folha de Baccharis dracunculifolia DC. (Asteraceae) visando a identificação da origem botânica da própolis. Acta. Bot. Brasílica, 12, 431-439.

Ortins, G. M. M. and Akisue, G. (2000), Estudo morfohistológico, screening fitoquímico, constantes físicas e análise cromatográfica da droga e extrato fluido 
visando controle de qualidade da espécie Baccharis articulata Pers. Lecta, 18, 9-32.

Pagni, A. M. and Masini, A. (1999), Morphology, distribution and histochemistry structures in vegetative organs of Santolina leucantha Bertol. (Asteraceae). Isr. J. Plant Sci., 49, 257-263.

Roeser, K. R. (1972), Die Nadel der SchwarzkieferMassenprodukt und Kunstwerk der Natur. Mikrokosmos, 61, 33-36.

Sá, M. F. A. and Neves, L. J. (1996), Contribuição ao estudo das plantas medicinais Baccharis myriocephala DC. Rev. Bras. Farm. 77, 88-96.

Sass, J. E. (1951), Botanical microtechnique. 2nd ed. Ames: Iowa State College.

Silva, J. B. and Grotta, A. S. (1971), Anatomia da folha e óleo essencial de Baccharis retusa DC., Compositae. Rev. Farm. Bioq. USP. 9, 321-326.

Souza, W. (1998), Técnicas básicas de microscopia eletrônica aplicadas às Ciências Biológicas. Rio de Janeiro: Sociedade Brasileira de Microscopia Eletrônica.
Torres, L. M. B.; Gamberini, M. T.; Roque, N. F.; Lima-Landman, M. T.; Souccar, C. and Lapa, A. J. (2000), Diterpene from Baccharis trimera with a relaxant effect on rat vascular smooth muscle. Phytochemistry: 55, 617-619.

Verdi, L. G.; Brighente, I. M. C. and Pizzolati, M. G. (2005), Gênero Baccharis (Asteraceae): Aspectos químicos, econômicos e biológicos. Quím. Nova, 28, 85-94.

Weimann, C.; Göransson, U.; Pongprayoon-Claeson, U.; Claeson, P.; Bohlin, L.; Rimpler, H. and Heinrich, M. (2002), Spasmolytic effects of Baccharis conferta and some of its constituents. J. Pharm. Pharmacol., 54, 99-104.

Zardini, E. M. (1984), Etnobotánica de compuestas argentinas con especial referencia a su uso farmacológico. Acta Farm. Bonaerense, 3, 77-99.

Received: April 12, 2007; Revised: May 13, 2008; Accepted: May 05, 2009. 